\title{
A "Neo No-Fault" Contract In Lieu of Tort: Preaccident Guarantees of Postaccident Settlement Offers
}

\author{
Jeffrey O’Connell $\uparrow$
}

The present method of compensating accident victims is both wasteful and ineffectual. Litigation is staggeringly costly for litigants and for society as a whole. Nonetheless, each year the volumc of litigation increases, leading to a clogged court system. It can often take several years to resolve a case, and accident victims are often desperately in need of money during that time. When a case is finally resolved by the courts, there is no guarantee of a just outcome. Who, indeed, has the capacity to decide with precision the vague, complex, or hotly contested issues that accident cases typically present? The upshot is that such cases are often not disposed of on the basis of actual fault or need. As a result, pretrial settlement operates inefficiently because both sides must base planning decisions on the predicted results of inherently unpredictable court trials.

One might be willing to overlook some of these shortcomings of the current fault-based system if it operated efficiently or produced just results. It does neither. The purpose of this Article is to suggest a scheme that would partially replace the existing regime. Under my proposal, accident victims would be compensated through preaccident nofault agreements.

I

Some Background on the Problem

\section{A. The Ills of the Tort System}

\section{Payment Based on Fault}

A major drawback of the current system of tort compensation is that the plaintiff's recovery for his injuries depends on his ability to prove that the defendant's conduct or product was at least partly at fault. ${ }^{1}$

$\dagger$ John Allan Love Professor of Law, University of Virginia. B.A. 1951, Dartmouth College; J.D. 1954, Harvard.

1. In jurisdictions where contributory negligence is a complete bar to recovery, the plaintiff must prove that the defendant was at fault and rebut defendant's evidence that the plaintiff contributed im some way to his own injury. The burden of proving contributory negligence, however, is on the defendant. W. Keeton, D. Dobrs, R. Keeton \& D. OWen, Prosser and Keeton on the LAW OF TORTS $\S 65$, at 451 (5th ed. 1984). In comparative negligence jurisdictions, the plaintiff 
Proof of fault is often very difficult. Extensive time and effort are required from the parties, lawyers, insurance adjustors, and, in technical areas such as products liability and medical malpractice, from expensive expert witnesses. Even im relatively straightforward cases, the parties and their experts will have opposite, often arcane, theories. Why, for example, did a hair dryer become overheated, severely burning its user? Or, when is the transverse position of a fetus so dangerous that a caesarean section should be perfornied to avert the mother's death?

The inherent difficulty of proving fault leads to huge transaction costs. $^{2}$ Cases are settled or tried based on exhaustive offers of proof from both sides, many months or years after the event. ${ }^{3}$ At trial, proof is adduced before often confused juries left to guess what really happened and who, if anyone, was at fault. The result is that many accident victims are left either totally or relatively unpaid for their losses, while others in similar or identical circumstances are awarded far more than their actual losses. It is a small wonder that the tort system is often characterized as a lottery with expert lawyers on both sides, even during the trial, at a loss to advise clients who will win what, or when. ${ }^{4}$

\section{Payment for Pain and Suffering}

Like establishing fault, translating a noneconomic loss such as pain into dollars is an extremely uncertaim process fraught with large transaction costs. Highly emotional evidence and arguments are at a premium as both sides try to win the sympathies of the jurors. ${ }^{5}$ Michael F. Colley, a leading plaintiffs' lawyer, admits that 'juries vote based on their impressions, their feelings, their biases, and their prejudices, not the facts

must show either that the defendant was mostly at fault ( $51 \%$ rule), that the plaintiff was no more at fault than the defendant ( $50 \%$ rule), or merely that the defendant was partly at fault ("pure" comparative negligence). Id. $\S 67$, at 471-73.

2. These costs have been extensively documented in numerous studies. See, e.g., O'Connell, An Alternative to Abandoning Tort Liability: Elective No-Fault Insurance for Many Kinds of Injuries, 60 MiNN. L. REv. 501, 503-12 (1976); see also Fleming, The Collateral Source Rule and Loss Allocation in Tort Law, 54 Cal.IF. L. REV. 1478, 1536 n.236 (1966).

3. Plaintiffs' lawyers often state that it is only because defendants and their insurers resist legitimate payment that hitigation turns into "war." Here they delude themselves. The same lawyers passionately support an adversarial system of tort law based on accusations-and counteraccusations-of wrongdoing. Under tort law, msurance is paid only if someone or something was at fault in injuring a victim who was free from fault (or relatively so). Why, then, should lawyers be surprised when accused defendants deny any wrongdoing or, in return, accuse the claimant of being in the wrong? Why, in other words, should personal injury lawyers be offended when their blows are answered? A necessary coneomitant of a fault-finding system is hard-fought hitigation.

4. See E. Bernzweig, By Accident, Not Design: The Case for Comprehensive INJURY REPARATIONS (1980); J. O'CONNELL, THE LAWSUIT LOTTERY: ONLY THE LAWYERS WIN 3-8 (1979) [hereinafter cited as J. O'CONNELL, LOTTERY]; J. O'CONNELL, ENDING INSULT TO INJURY: No-Fault INSURANCE For PRoducts AND SERvices 3, 54 (1975) [hereinafter cited as J. O'CONNELL, INSULT].

5. See J. O'CONNELL, LOTTERY, supra note 4, at 29-34, 62-64. 
of the case." He states that the credibility of expert witnesses, supposedly testifying on matters of scientific precision, often turns on "their language, style, and body codes and cues." The result is often very dissimilar awards for very similar injuries.

Valuation of injuries of similar severity but differing visibility also fiuctuates widely. Jurors will award substantially less for a seriously injured back or other injury they cannot see, than for a more visually striking injury such as extensive scarring.

The emphasis on emotional impact means that injury victims are encouraged to prolong their handicaps in order to impress juries with their pathetic conditions. Compensation for pain and suffering makes medical recovery inconsistent with legal recovery. ${ }^{7}$ Consequently, therapists often despair of effectively treating seriously-injured accident victims undergoing a long delay before trial. Because of this primary focus on the patient's legal rather than medical prospects, temporary partial disabilities can become permanent and even total disabihities. ${ }^{8}$

Basic econoumic theory teaches us that generously rewarding pain and accompanying misery creates a strong incentive for suffering. Indeed, the primciple of indemnity, which is the very essence of insurance, bans paying any insurance money beyond a party's actual economic loss because to do so is to encourage the insurance payee to incur a loss. ${ }^{9}$ Nowhere in all of insurance does violation of the principle of indemnity lead to such rampant waste as does payment for pain and suffering. How better to document one's suffering than by prolonged absence from work and repeated trips to the doctor? Both practices are not only wasteful in themselves but are subsidized by the third blight on personal injury tort law, the "collateral source" rule.

\section{Payment by the Tortfeasor for Expenses Already Reimbursed by Collateral Sources}

Under the "collateral source" rule, a defendant may not plead, as mitigation of dainages, compensation that the plaintiff has received from a source uncoimected with the defendant. This rule is an exception to the general rule that a plaintiff may not recover more damages than he has actually suffered. Thus, a plaintiff who has received payments from his own insurer inay still recover his total damages from the defendant in

6. Taylor, Trial Lawyers Trade Tips and Practice Presence, N.Y. Times, July 28, 1981, at B20, col. 1 (quoting Colley's remarks to fellow lawyers at the Association of Trial Lawyers of America 1981 annual convention).

7. J. O'CONNELL, LOTTERY, supra note 4, at 21-22.

8. Letter from a member of the Committee on Trauma, American College of Surgeons (May 4,1964 ) (on file with the author).

9. See O'Connell, A Proposal to Abolish Defendants' Payment for Pain and Suffering in Return for Payment of Claimants' Attorneys' Fees, 1981 U. ILL. L. REV. 333, 344-47. 
a tort action. ${ }^{10}$ This double payment leads either to further profit for the accident victim or to subrogation claims by the collateral source. In the former case, an eligible accident victim can receive an additional dollar from the tortfeasor for every health insurance dollar expended. ${ }^{11}$ This procedure amounts to coining money! If there is subrogation, the collateral source, rather than the payee, is repaid by the tortfeasor. This result, too, is socially unhealthy. Loss already efficiently born by first-party insurance is shifted to the tortfeasor at great cost and without any appreciable social benefit. ${ }^{12}$

\section{The Plight of Accident Victims}

The tragedy of serious personal injury claims today is the degree to which both insurers and plaintiffs' lawyers are in a position to exploit accident victims' desperation and ignorance. A typical injury victim, even after hirmg an expert lawyer, cannot be told what he will be paid, when he will be paid, or even if he will be paid. This creates an enormous advantage for the defendant's insurer. Unhike the severely injured claimant, the defendant's insurer is not intimidated by all the uncertainty; it is an institutional expert on such matters. The insurer is not risking all on one claim. On the contrary, an insurance company is by definition a classic means of diversifying risks with actuarial certainty among all the company's policyholders. Even if a risk is of sufficient magnitude to threaten all the company's policyholders combined, the insurer can reinsure a large risk with still other insurance compamies. Consequently, an insurer is in no hurry to settle a personal injury claim. The longer it can delay, the longer it can keep earning interest on whatever amount it ultimately must pay, assuming it loses. Furthermore, the longer the delay the defendant threatens by exploiting doubt concerning both the fact and amount of liability, the more desperateand inore inclined to accept a comparatively low settlement-the injured clainant inay becoine. ${ }^{13}$ Consequently, insurers are reluctant to make

10. See Naton v. Bank of Cal., 649 F.2d 691, 699 (9th Cir. 1981) ("Under the collateral source rule, benefits received by an injured party from a source wholly independent of the wrongdoer should not be deducted from the damages that the wrongdoer otherwise is compelled to pay the injured party."); see also Fleming, supra note 2, at 1478 ("[I]n computing damages against a tortfeasor, no reduction [is] allowed on account of benefits received by the plaintiff from other sources, even though they have partly or wholly mitigated his loss.").

11. O'Connell, supra note 9, at 334-37.

12. Fleming, supra note 2 at 1536-37.

13. As long ago as 1936, Professor Emma Corstevet depicted the vulnerable bargaining position of the seriously injured accident victim. An accident victim with a severe disability who is a family breadwinner with limited health or disability insurance benefits is usually in a pathetically inadequate bargaining position against an insurer whose stance, because of the very nature of bargaining, grows stronger with delay:

[T] claims [the insurer] is not anxious to buy at all unless the horizon is really threatening 
prompt offers of relatively generous settlements in personal injury cases. They have no economic incentive to make such offers since it is adversarial claimants, not their own pohicyholders, who suffer most from delay. $^{14}$

It is bad enough that claimants are so often overmatched by the other side; it is even worse that they can be ambushed from their own side by their own lawyers. Typically, a personal injury victim has had no prior dealings with his lawyer and will never see him or her again. Thus, the feehing of trust and confidence that often pervades a continuing relationship between lawyer and client may well be absent. ${ }^{15}$

Defendants and msurers are aware of this lack of trust and confidence. Therefore, even if a defendant or an insurer is inclined to make a relatively prompt offer of settlement, the offer is likely to be very lowwell below the claimant's net economic loss-for two reasons. First, if the plaintiff's lawyer is mcompetent or unethical, he may be willing to accept a low offer to earn a quick contingent fee. A lawyer, for example, can earn one-third of $\$ 100,000$ alinost without working, whereas holding out for a share of a larger verdict involves not only the possibility of losing the case, but also the certainty of expending much more time and effort in pursuing it. ${ }^{16}$ Second, an early offer, equaling the claimant's net economic loss, may simply excite an energetic claimant's counsel to hold out for much more. A further irony is that the claimant's lawyer may reject even a substantial offer from an insurer due to the lawyer's desire to pursue the case to trial. A partner in a major accounting firm who often works with lawyers opmes that, contrary to their clients' interests, claimants' lawyers often pursue personal injury cases to trial rather than

[which will happen only after many years, given court congestion], the seller [the injured] must sell to this buyer or none at all. His costs have been forced from him, he must recoup what he can. And if the outlay has been serious, the injured often needs moncy and at once. [The victim's income and obligations ordinarily leave] little leeway for unforeseen emergencies. The family doctor may wait, the landlord may be generous, the grocer, up to his limited means, give credit. But a nurse is not a capitalist, and needs her wage at once, a specialist is not the family doctor, the need for [fuel] and light, medicine, special sick foods and some unavoidable necessities of family living goes on. The result is that the families most in need of compensation can often least afford to hold out for an adequate price, i.e., a price commensurate with expenditure and as great as those who can afford to wait might obtain.

Corstevet, The Uncompensated Accident and Its Consequences, 3 LAW \& CoNTEMP. ProBs. 466, 468 (1936).

14. J. O'CONNEll, The INJURY INDUSTRY AND THE REMEdy OF NO-FAult INSURANCE 21-26 (1971).

15. Id. at 47 (quoting H.L. Ross, SeTtLed OUT of Court: THE SOClal Process of InsurANCE Claims Adjustment (1970)); O'Connell, Offers that Can't Be Refused: Foreclosure of Personal Injury Claims by Defendants' Prompt Tender of Claimants' Net Economic Losses, 77 Nw. U.L. REV. 589, 604-05 (1982).

16. See J. O'ConNell, supra note 14, at 44-45 (quoting F. MACKInNON, ConTINGENT FeE5 for Legal Services; A Study of Professional ECONOMics AND Responsibilities 116 (1964)). 
settle them. ${ }^{17}$ Lawyers know they are going to lose many, if not most, of the cases that go to trial. But, the accountant says, lawyers take cases to court "because they only need one to hit the jackpot and be set for hife. Settling a case means cuttimg down the odds agamst the big, big win."18 According to the National Law Journal, "[L]awyers admit the likely conflict but point out that it's inherent in the job." 19

The basic problem here stems from the almost total ignorance of personal injury claimants concerning their rights-an ignorance that both plaintiffs' lawyers and insurers can exploit. In candor, neither plaintiffs' lawyers nor insurers are motivated to change the situation. Personal injury litigation is probably the most lucrative area of law in the United States-dwarfing even the returns from Wall Street firms. ${ }^{20}$ Personal injury lawyers are not tied to their time sheets which, even at $\$ 200$ $\$ 300$ an hour, hmit income to about $\$ 300,000$ annually. Instead, personal injury lawyers share in the equity from huge verdicts and settlements, earning annual incomes that can approach or exceed $\$ 1,000,000.21$ The insurance industry is also unhkely to encourage change. Because of its familiarity with and profits from the present system, the industry prefers to maintain the status quo. ${ }^{22}$

\section{B. A Case Study}

The nature of the prolonged, expensive, and agonizing litigation arising from personal injuries, and the often irreconcilably conflicting testimony over elusive, and indeed often illusive, facts is illustrated by a recent District of Columbia case. Carl Green was a seventeen-year-old football player at Anacostia High School when the nerves in his left arm

17. Grenelli, Damages: How Much To Ask For, Nat'l. L.J., July 27, 1981, at 1, 31, col. 2.

18. Id.

19. Id.

20. N.Y. Times, May 16, 1977, at 35, col. 3:

"There is no question about it," says Lawrence E. Walsh, a partner in Davis, Polk \& Wardwell .... "In terms of accumulation of wealth and living style, senior lawyers [on Wall Street] are not matching those of the 1920's. The top of the personal-injury bar does better than [Wall Street] partners."

21. Id.; see also J. O'CONNELL, LOTTERY, supra note 4, at 135-36.

22. O'Connell, supra note 15 , at 627-28:

[A] much improved tort system-especially one that eliminates delay over disputes as to who [or what] was at fault and that eliminates payment for pain and suffering or duplicated collateral sources-could result in a much smaller investment return by decreasing the amount of reserves and the time in which those reserves can earn a return. . . . Added to the fears of those particular changes is the insurance industry's fear of change per se. One of the greatest assets of insurance companies is their bank of actuarial data based on past claims. Changes in rules for future claims threaten the validity of such actuarial data. Rarely, then, will casualty insurance companies push for revolutionary changes in tort law....

Id. 
were severed while he was making a tackle in a 1974 interscholastic game:

Greene had contended that his left arm was first injured during a practice and that [Anacostia] coach Wyinan Colona negligently put him in the lineup two weeks later for Anacostia's homecoming game against Spingarn High School, in which Greene's arm was permanently paralyzed.

Colona contended at the trial that Greene had never reported a serious injury prior to [the Spingarn] game.

Greene testified that he told Colona of "burning and timgling" in his arm after the injury during a practice. Colona testified that Greene had reported only a bruise.

According to Greene, the original injury occurred duriug a practice a few days after Anacostia played its first 1974 regular conference game. Greene, who played as a hinebacker, told the jury it was nearly dark when an offensive player broke through the line with the ball, and Greene tackled him.

Colona testified that he did not hold practices in the dark and that practices during the regular season did not include tackling.

According to Greene, Colona placed him in subsequent games after putting extra padding on the injured left shoulder. Colona said the paddimg had been placed on the right shoulder to protect a bruise.

Greene and former defensive teaminates, as well as the team's defensive coach at the time, testified that Colona discouraged reporting of injuries.

Other former players and coaches who testified for the City said Colona had the safety of his players uppermost in his imind and would never have put Greene in the lineup had he lenown he was seriously injured.

A medical expert who testified on Greene's behalf said the nerves in the arm could not have been severed unless Greene had been injured previously.

A medical expert appearing for the City testified that there was no indication Greene had suffered any earher damage to the arin.

City officials said at the trial that school medical records that inight have documented an earher injury [could] no longer be found. ${ }^{23}$

The case finally came to trial in 1983, almost nine years after the imjury, and resulted in a $\$ 1.5$ milhion verdict for Greene. ${ }^{24}$ The city immediately appealed, and, after more uncertainty and delay for the accident victim, the judgment was eventually reduced to $\$ 975,000$. $^{25}$

23. Wash. Post, April 23, 1983, at Al, col. 1, A8, col. 3.

24. Id. at $\mathrm{Al}$, col. 1 .

25. Wash. Post, Nov. 13, 1984, at A10, col. 3. 


\section{Prior Proposals}

\section{A Prior Legislative Proposal}

As at least a partial solution to the problems of tort liability for personal injury-a solution that would likely assure much more timely and more efficient payment of genuine losses for many accident victimsI recently suggested the following: ${ }^{26}$ a statute under which a potential defendant would be given the option of foreclosing any claim for personal injury against him by offering within a brief fixed time ${ }^{27}$ to begin paying periodically the claimant's net economic loss. In most cases this loss would consist of medical expenses and wage loss above any amount already paid by the claimant's own insurance. Payment would also include reimbursement of claimant's reasonable legal fees, if any, in addition to claimant's actual losses. Claimants would then be obligated to accept such payment of their net economic loss in total satisfaction of personal injury claims, except in cases of death or imtentional injuries. ${ }^{28}$

As a furtlier incentive for defendants to tender claimants' net economic losses, the proposal could provide that a defendant thus settling need pay no more than, for example, twice the average weekly wage in the state. This provision would mean that inore affluent victims with larger wage losses would be inore likely to have their wage loss clains substantially lessened, but this is precisely what happens today under workers' compensation. Indeed, we can expect the inore affiuent to have covered their wage loss above the ceiling through their own insurance tailored to their own needs.

The problein with my proposed statute is just that-it entails passing a statute. ${ }^{29}$ There are three main difficulties with trymg to effect reform through legislation. First, it is difficult to get the attention of today's legislature about any issue. Second, it is all the more difficult to get a legislature to pass controversial legislation. This is especially so in the face of very effective lobbying opposition. Tort reform is opposed by powerful trial-lawyer lobbies that are often mdependently aided by insurers hostile or indifferent to sweeping change. Third, any legislation that

26. O'Connell, supra note 15 , at 601-03. A bill based on this proposal, H.R. 5400, sponsored by Representatives Henson Moore (R. La.) and Richard Gephardt (D. Mo.), is before the Congress, and would apply to medical malpractice claims. Moore \& O'Connell, Foreclosing Medical Malpractice Claims by Prompt Tender of Economic Loss, 44 LA. L. REv. 1268 (1984).

27. My original article proposed a period of 60 days. O'Connell, supra note 15 , at 601 . The precise time period, between 60 to 180 days, is largely a matter of the drafter's discretion.

28. O'Connell, supra note 15, at 601-02. For alternative means of delineating what tort claims are preserved, see Moore \& O'Connell, supra note 26, at 1282.

29. Cf. G. Calabresi, A Common Law for the Age of Statutes (1982); Keeton, Creative Continuity in the Law of Torts, 75 HARv. L. REV. 463 (1962); Peck, Comments on Judicial Creativity, 69 IowA L. REv. 1 (1983); Peck, The Role of the Courts and Legislatures in the Reform of Tort Law, 48 MinN. L. REv. 265 (1963). 
does emerge may well be so watered down or distorted as to ill serve the objectives originally sought. For example, inadequate no-fault auto insurance laws provide for large no-fault benefits, but preserve too many tort claims. Such reform is expensive and may even be unworkable. ${ }^{30}$

\section{Prior Contractual Proposals}

In order to avoid the pitfalls of legislation, I have in the past proposed elective no-fault insurance whereby at the time of sale of a product or service, a seller could at its option bind itself to offer no-fault benefits for economic (but not noneconomic) loss in the event of a resulting personal injury. At the same time, the injury victin would have the option to bind himself to accept no-fault benefits in heu of a tort claim. ${ }^{31}$ Although I have argued that such a contract, entailing a valuable quid pro quo for surrender of tort rights, would be upheld by the courts, ${ }^{32}$ others (especially practicing lawyers advising businesses and health-care providers) have questioned whether a potential accident victim can validly waive his or her tort claim prior to injury, even in return for a guarantee of no-fault benefits. ${ }^{33}$

II

\section{A New Contractual Proposal}

In order to avoid the difficulties with previous proposals, I hereby make a new proposal which might be termed "neo no-fault." This proposal does not entail a statutory guarantee of no-fault benefits to mandatorily replace tort liability traditionally associated with workers' compensation and no-fault auto statutes. ${ }^{34}$ Nor does it entail "add-on no-fault," whereby no-fault benefits are provided with no restriction on

30. Such laws abrogate the basic bargain envisaged by no-fault, namely a substitute of the nofault remedy of some payment for economic loss to all victims for the tort remedy of payment of both economic and noneconomic loss to some victims. In other words, no-fault plans substitute payment of "some for all" for payment of "all for some." If "some for all" is simply added on to "all for some," the result is clearly higher insurance costs. See N.Y. Times, July 17, 1983, at E7, col. 1; Wall St. J., Nov. 16, 1983, at 1, col. 6.

31. O'Connell, Elective No-Fault Liability by Contract With or Without an Enabling Statute, 1975 U. ILL. L.F. 59; O'Connell, No-Fault Liability by Contract for Doctors, Manufacturers, Retailers and Others, 1975 INs. L.J. 531 [hereinafter cited as O'Connell, No Fault for Doctors].

32. O'Connell, No Fault for Doctors, supra note 31, at 537-45.

33. This was the clear consensus of a group of lawyers from various states at a meeting of the National Federation of State High School Associations in Kansas City, May, 1982. But see O'Connell, Transferring Injured Victims' Tort Rights to No-Fault Insurers: New "Sole Remedy" Approaches to Cure Liability Insurance Ills, 1977 U. ILL. L.F. 749, 789-91 \& n.136. For an article echomg my arguments on the validity of preaccident commitments to accept no-fault benefits to replace the contingency of payment based on fault, see Epstein, The Historical Origins and Economic Structure of Workers' Compensation Law, 16 GA. L. REV. 775, 789-97 (1982).

34. See J. O'CONNELL, LOTTERY, supra note 4, at 159-62, 192. 
tort liability claims above no-fault benefits. ${ }^{35}$ Under this proposal, any seller of products or services can put in effect an insurance policy or product warranty binding the seller to tender, within ninety days of a claim for an injury resulting from the defendant's product or service, the victim's net economic loss regardless of the existence of tort hability in any particular case. In other words, the seller would bind itself to make the tender regardless of whether the injured party could prove that the defendant's conduct or product was faulty and that he was free from contributory or comparative fault. Net economic loss would include any resulting medical expenses, including rehabilitation and wage loss (possibly with a cap of some fixed amount), beyond the victim's own collateral sources such as accident and health insurance or sick leave. ${ }^{36}$ Benefits would be payable month by month as loss accrued. The victim and anyone with a claim based on the victim's injury, such as members of his family, would be given ninety days from the date of tender to accept such tender or to claim in tort. ${ }^{37}$ In other words, upon acceptance of the nofault tender of net economic loss, the victim would be required to waive his tort claim against the tendering party.

Such an insurance program might entail unusual risks of unpredictable costs for an insurer. In order to soften those risks, the tendering party could require the victim to waive tort claims not only against the tendering party but also against third parties. The tendering party would then gain leverage to obtain a contribution to the pool of insurance funds required to pay net economic losses from any third party who may have contributed to the accident. The tendering party could exact the contribution at the start of the policy period, making the third party an additional insured under the pohicy in return for an annual contribution to the policy's premiums. The insurance contract might also allow the tendering party at the time payment is tendered to designate a third party as also benefiting from the waiver of tort claims in return for a contribution to the pool. The tendering party and third party would not need to agree immediately on the amount of the third party's contribution under either a preaccident or postaccident sharing agreement; rather the parties might agree to arbitrate at their convemience their respective shares of the no-fault damages or pool. The point is that under this scheme, a healthcare provider could receive assistance in funding its tender from other

35. Id. at 161-62, 172.

36. The wage loss could be indexed to inflation, but many insurers resist doing so.

37. The policy could be written so that the party against whom a personal injury claim is made could make the tender not only within 90 days of a claim but, at its option, before a claim is made. That way a potential payor could not be forced to wait until just before the statute of limitations has run to tender the victim's net economic loss. Rather it could do so at any point after injury, thereby starting the 90-day period withm which the claimant would have to decide to accept the tender or not. 
health-care providers treating the patient, or even a surgical-instrument manufacturer. Similarly, a manufacturer of a product could extract the same help from a coinponent-parts manufacturer. There would be enormous pressure on third parties potentially liable in tort to join in the program on either a preaccident or postaccident basis. If third parties did not join, they would face a much more aggressive injured claimant, who, like a workers' compensation recipient pursumg a third-party tort claim, would have been assured of his or her basic losses, and would thus be much more able to resist low settlement offers than would a normal, impecunious injury victim. ${ }^{38}$

The proposed scheme is not as appropriate for nonserious injuries. For example, unless their injuries are serious, victims of defective products or neghigent health-care dehvery are less hikely than victins of slips and falls or auto accidents to pursue tort claims. ${ }^{39}$ Even when liability is relatively clear, if the victim's loss from a defective product or negligent medical service is only a few thousand dollars and there is no residual disability, it is often not profitable for a competent plaintiffs' attorney to pursue the case. ${ }^{40}$ Thus, from the viewpoint of a health-care provider or a product seller, it would ordinarily not inake sense to offer a no-fault compensation systein covering less serious injuries since they result less often in payment under the current system. Secondly, unless an accident victim from whatever cause who has a vahd tort claim suffers serious injury, he will not be mclined to accept tender of prompt payinent of net econoumc loss in return for his tort claim. He is not in need of such prompt payment and can afford the risk of tort litigation. The result is adverse selection ${ }^{41}$-namely payment to all those without valid tort claims, with no corresponding reduction of tort claims out of which to pay those newly eligible claimants.

To circumvent this problem, a contract calling for the tender of net

38. J. O'CONNELL, LOTTERY, supra note 4, at 216:

[U]nder workers' compensation acts, employers guarantee on a no-fault basis all medical expenses and at least subsistence wage loss to employees injured on the job in return for the employee's surrender of his [tort] claim against his employer.

Through the years plaintiffs' lawyers have realized that although the employer is thus exempt from [tort] hability, third-party supphers of industrial equipment to the place of einployment, supphiers of such things as punch-press machines, are not. The result has been a rising number of so-called third-party product liability suits. According to one study, almost one-half of the total of product hability payments for personal injury (42 percent) went to employees injured on the job and therefore presumably already covered by workers' compensation.

39. This is because the former claims involve teehnical engineering and inedical evidence, usually in the form of expensive expert witnesses. Thus, only the most serious injuries may warrant the kind of investınent required. Id. at 177-78 (citing Belli, Product Liability and the Injured Party, in 1 World Congress on Product Liability 177 (1977)); J. O'Connell, INsult, supra note 4, at 17-18; O'Connell, An Elective No-Fault Liability Statute, 1975 INs. L.J. 261, 290.

40. O'Connell, supra note 39, at 290.

41. R. Keeton, Basic Text on Insurance LAW § 1.2(b), at 8-9 (1972). 
economic loss can be structured, at the option of the health-care provider or product seller, to exclude smaller cases. For example, the contract could include a deductible of $\$ 10,000$ of actual medical expense or wage loss below which the tender need not be made. In addition, further restrictions on the definition of the insured event could be devised. In the surgical area, for example, tender could be limited to cases of adverse surgical results involving severe brain damage or paralysis. Alternatively, tender could be limited to adverse results in surgery conducted on a clean operative field (i.e., one not contaminated by infection), with certain areas of the body such as rectal, vaginal, and colonic areas, and burn sites specifically defined as unclean operative fields. ${ }^{42}$ Furthermore, adverse results, other than those resulting from failure to diagnose, could be defined so as to exclude those that are directly related to the predictable progression of the illness or disease that caused hospitalization in the first place. ${ }^{43}$ Finally, whether for malpractice or product cases, the obligation to tender could be limited to a pilot program covering a specific period or place after which the results of the prograin could be assessed.

In addition to payment of the claimant's actual losses, the insurance contract should require payment of claimant's counsel fees for advice concerning the tender. ${ }^{44}$ Counsel fees should arguably not entail payment for investigating the wisdom of a tort action. The claimant's attorney's fee could be premised on the proposition that any time spent by lawyers investigating a possible tort claim is an investment redeemable only by a contingent fee in a tort action. Thus, when the decision not to pursue a tort action is made, the amount of an attorney's fee can be limited to an hourly fee for services rendered in connection witl submitting the economic loss to the tendering party. Claimants' lawyers who would stand to receive the larger contingent fee in the event of tort litigation will have a conflict of interest with their chents. They miglit be unduly infiuenced in their advice by how inuch inore they stand to benefit from a tort action than from acceptance of the tender. In order to circumvent

42. The latter is one approach to defining criteria for no-fault payment adopted by an organization called Health Iuuovations, Inc., of Durham, N.C. headed by Jeffrey Johnston in collaboration with Dr. Eugeue Stead of the Duke Medical School.

43. A further exception might be made for certain instances of express assumptiou of risk as in cases of, say, optional back operations, where the risks of poor results are very high.

44. If attorney's fees were not included, a claimant would have to pay his lawyer with inoney intended to cover his medical expense and wage loss. See O'Connell, supra note 9, at 351-53.

The contract would expressly exclude payment to a lawyer who advises a victim not to accept the tender, since the lawyer would be charging a contingeut fee-which would be paid by the insurer as part of any resulting settlement or verdict-in the tort claim. Paymeut of counsel fees only for advising acceptance of the tender may create an ethical problem, in that it could be viewed at inducing counsel to advise acceptance. However, this may be the only sensible approach; it seems unfair that the insurer should be forced to pay both the counsel fees charged for advising the claimant to reject the tender and, assumiug that the plaintiffs tort action is successful, the contingent fee charged for winning the case. 
this problem, the insurer could obligate itself to pay the cost of a second attorney's opinion, at the claimant's option, whenever the claimant is advised by his lawyer to reject a tender. To avoid a second conflict, the second attorney could be required to certify that he will not, directly or indirectly, represent any claimant in a related tort action. ${ }^{45}$

This device is redolent of insurers' practice of seeking a second doctor's opinion before financing surgery. Thus, it should be acceptable to insurers and the courts. In both cases, a professional is perceived as having a conflict of interest. Surgeons like to operate, and lawyers like to litigate; they each receive larger fees for doing so. The claimant would not, however, be required to obtain a second legal opinion.

\section{III}

\section{Comparison with the Present System}

How does a preaccident guarantee to make a postaccident tender of net economic loss differ fron 1 an identical postaccident offer of settlement under present law? In the first place, such settlenient offers do not often arise today. As stated before, defendants rarely inake early offers sufficiently generous to cover a plaintiff's economic loss, past and future. Defendants fear that such offers will encourage plaintiffs, and especially their lawyers, to believe that they can recover even more if they persevere through hitigation. Plaintiffs and their lawyers would frequently reject such offers because they would simply see them as signs that their case was worth niuch more. ${ }^{46}$ Because the tender under my proposed contract is niade pursuant to a preaccident guarantee before the precise causation or circumstances of any injury can be known, it is not a signal by the defendant of the weakness of its case. This niakes it inuch more attractive for a defendant to nrake a tender. Second, the preaccident nature of the guarantee undercuts the potential bias of the defendant in only tendering paynient in cases where liability is clear. Thus, the prejudice associated with a pronipt postaccident offer of a relatively generous settlement is avoided.

As suggested before, to assure that a tender of net economic loss would entail no admission of tort hability, the preaccident definition of the insured event inust be sufficiently broad to include nore than just those cases of clear tort hability. Otherwise, the tender would smack of a signal of defendant's weakness. ${ }^{47}$ This does not mean that the definition could not enconipass mostly those cases where there is tort liability. As long as a significant nunber of cases involving unclear tort liability were

45. Unlike the situation discussed above, see supra note 44 , payment for a second opinion would be made regardless of whether counsel advised acceptance or rejection of the benefits.

46. See supra notes 16-17 and accompanying text.

47. See supra text accompanying notes $16-17$ and 46 . 
included in the definition, the purpose of the plan would be served. On the other hand, even in the category of cases where liability is relatively clear, the clainant's burden of proof in any given case can be extremely taxing. ${ }^{48}$ For this and other reasons suggested above, the definition of covered events might still be tailored to cases where the commitunent is unlikely to result in overall burdens greater than those imposed by tort liability. ${ }^{49}$ Payment of net economic loss could result in huge savings by reducing defense costs and eliminating payment for pain and suffering and from duplicate sources. In other words, if claim frequency will increase under the tender plan, average claim cost will be drastically reduced. ${ }^{50}$

A postaccident option of accepting or rejecting payment of net economic loss may bring up the possibility that those claimants with valid tort claims would choose to go to court while those with invalid claims would accept the tender (another example of adverse selection). ${ }^{51}$ However, claimants who have suffered serious injury are likely to become risk averse even if they have an arguably valid tort claim when given a choice between certain, if limited, benefits and the gamble of a lawsuit..$^{52}$

If enough accident victims with serious tort claims are sufficiently risk averse to accept the tender of net econoinic loss, the savings would be great. Such tenders to all accident victims might be completely financed out of the savings resulting from surrender of tort claims, with no need for additional funds in the forin of higher prices for goods and services. If not, some additional funds inay be necessary, but these funds would transmit genuine value. The early twentieth-century employers who backed workers' compensation in return for surrender of tort rights were not at all sure what the new no-fault benefits would cost coinpared to tort liability. Nevertheless, they were willing to gamble that either the

48. See supra text accompanying notes 1-3.

49. See supra text accompanying notes $39-43$.

50. For an indication of how inexpensive payment of no-fault benefits is when compared to payment of common law damages under tort law, see the forthcoming articles Joost \& $O^{\prime}$ Connell, Removing Fault(s) from No-Fault, and Joost \& O'Connell, Giving Motorists a Choicc.

51. See R. KeEton, supra note 41.

52. This has been the (admittedly limited) experience under a high school athletic program offering athletes a postaccident tender option. Since its inception in 1982, all 11 eligible seriously injured athletes have opted under this plan to accept no-fault benefits and waive their common law rights. See infra Part IV. The experience of jurisdictions that allow an employee injured by an unintentional tort of an employer to claim either tort damages or workers' compensation also demonstrates that claimants will choose the certainty of a no fault claim rather than risk a tort action. Even though in these jurisdictions an unsuccessful tort suit does not bar a workers' compensation claim, most injured employees claim only workers' compensation benefits because of the delays im filing a claim and receiving benefits caused by initial pursuit of a tort claim. See 2A A. LARSON, THE LAW OF WORKMeN's COMPENSATION $\$ 67.31$ (1983 \& Supp. Dec. 1984); Love, Punishment and Deterrence: A Comparative Study of Tort Liability for Punitive Damages Under No-Fault Compensation Legislation, 16 U.C.D. L. REv. 231, 267 \& nn.224-25 (1983). 
benefits would not cost more, or a far saner insurance system would be worth any additional cost. At least some of their progeny will probably be willing to make the same bet today. Indeed, an extensive program covering school athletic injuries is already in place and operating in one state. ${ }^{53}$ While eleemosynary institutions such as schools, or even hospitals, may be more hikely to feel an obligation to their injury victims than commercial institutions, the moral and even commercial advantages flowing from sympathetic treatment of one's injury victims cannot be overlooked for all institutions. ${ }^{54}$ What is being sold under such contracts is, in effect, a group disability insurance contract, marketed by a product seller to its customers, by a health-care provider to its patients, or by a school to its athletes. The key advantage of this new contract is that it is financed largely or entirely by money formerly spent (or better said, misspent) on tort hitigation. ${ }^{55}$

If at least some defendants will be willing to trade their right to take advantage of injury victims' tort phight, ${ }^{56}$ how will victims' lawyers react? As noted above, ${ }^{57}$ a tender made pursuant to a preaccident coinmitinent before the precise causation or circumstances of any injury can be known is not a confession of weakness. Threats to take such an offer off the table after minety days are much more credible than they would be under the present system. Thus, plaintiffs' lawyers who advise seriously injured clients to reject a prompt but temporary offer covering essential losses could well face inalpractice actions if the gainble of tort litigation fails. Indeed, this insurance plan would be appealing to health-care providers and product sellers; it allows them effectively to strike back at the legal profession's perceived harassment through personal injury claims. ${ }^{58}$ Under this plan, plaintiffs' lawyers will be under pressure similar to that

53. See infra Part IV.

54. See J. O'CONNELI, INSULT, supra note 4, at 100-01, 107 n.8; see also infra note 64.

55. The contract I propose is a new combination of disability/liability insurance. 1t provides the equivalent of disability insnrance in return for a waiver of rights under liability insurance. This proposal will not mean, however, that as a practical matter less disability insurance will be sold. Disability insurance is sold episodically on a first-party basis (i.e., by one's own insurer) and covers all kinds of disability-including illness as well as accident. Thus, disability insurance will not be displaced by the new coverage just because some instances of disability may be covered by some tortfeasors' "neo no-fault" insurance as described above. Rather, the new insurance will be a means of supplementing whatever disability insurance now exists.

56. See supra text accompanying note 13 .

57. See supra text accompanying note 46 .

58. One county medical society president said of Melvin Belli, archetypieal personal injury lawyer, "Hanging is much too good for him. He should be made to suffer as we [doctors] have suffered." Silverman, Medicine's Legal Nightmare (Pt. 1), SAT. Evening Post, April 11, 1959, at 13. See also Lipman, Huge Malpractice Suits, Premiums Threaten Insurance and Health Care, Wall St. J., Sept 21, 1983, at 31, col. 3, at col. 5; id. at 54, col. 6:

"You aren't treating a patient," says Hugh Unger, a Miami orthopedic surgeon. "You're treating an adversary."

. . . Neurologist Henry McVeety plans to move from Westchester County in New 
which they impose on health-care providers and product sellers. That is, they must secure mformed consent from, or warn, clients about the risks of rejection of the tender, and face litigation after a poor result. ${ }^{59}$ Sucl pressures on plaintiffs' lawyers will likely lead to acceptance of the tender of net economic loss $^{60}$ and a consequent lessening of the strams and difficulties on liealth-care providers and product sellers that now result from claims by injured patients and consumers. ${ }^{61}$

My proposal in no way disadvantages accident victims. They retain exactly the rights they have under tort law, supplemented by an alternative of certain and quicker, but lesser, payment. Any person wishing to assert his tort riglits is free to do so. In this regard, the poor are most likely to be without their own collateral sources covering catastroplie; they are also least likely today to pursue a tort remedy and derive some benefit from the tort system. ${ }^{62}$ Thus, my proposal benefits those who most need compensation.

Moreover, the accident victim would no longer be helplessly dependent on the arcane issues of tort liability bargained over by his lawyer and the other party's insurer. While lie would not necessarily know the

York State to North Dakota to escape his $\$ 50,000$ insurance premium. Paying close to $\$ 1,000$ a week just to stay in practice, he says, "is absolutely ridiculous. It's extortion." "I've thought about packing it in myself," says Donald Stewart, 48 years old, a Syracuse, N.Y. neurosurgeon. "It's so unpleasant. You can't help people when they're out to get you."

59. Peck, A New Tort Liability for Lack of Informed Consent in Legal Matters, 44 LA. L. REV. 1289 (1984).

60. See supra note 52 .

43.

61. For more on these strains and difficulties, see J. O'CONNELL, INSULT, supra note 4, at 42-

62. In the words of $H$. Laurence Ross, a sociologist who has studied the tort liability system: The tort law in action may . . . be termed inequitable. It is responsive to a wide variety of influences that are not defined as legitimate by common standards of equity. The interviews and observations I conducted convinced me that the negotiated settlement rewards the sophisticated claimant and penalizes the inexperienced, the naive, the simple, and the indifferent. Translating these terms into social statuses, I beheve that the settlement produces relatively more for the affluent, the educated, the white, and the city-dweller. It penalizes the poor, the uneducated, the Negros and the countryman.

H.L. Ross, Settled Out of Court: The Social Process of Insurance Claims Adjustment $241-42$ (1970). Consider the following table:

Table 3.25. Relationship of Family Income to Serious Injury and Fatality [Automobile1 Cases, to Retention of Counsel, and to Reparations Received.

\section{Family income}

Under $\$ 5,000$

$\$ 5,000-9,000$

$\$ 10,000$ and over

Total
Percent retaining counsel

30.0

36.7

41.9

35.0
Ratio of net reparations to economic loss

(3)

0.38

0.52

0.61

0.49

1 United States Dep'T of Transp., Economic Consequences of Automobile Accident INJURIES 54 (1970) (Automobile Insurance and Compensation Study). The "reparations received" figures include both tort and nontort sources, with about one-third of recovery for bodily injury and property damage from tort. Id. at 2. 
value of his tort claim, he would be promptly provided with alternative benefits that would enable him to have greater command over his future than he ever had at common law. In other words, the victim would no longer be almost totally in the dark relative to the other parties to the transaction. And an enterprise that sells accident victims such an alternative has imparted real value that can inure to the enterprise's goodwill and profit. ${ }^{63}$

\section{IV \\ Neo No-Fault in Action}

I have drafted an insurance contract covering serious high school athletic mjuries which meets the specifications set forth in this Article. At this writing, the contract is im effect in forty-nine states under the auspices of the National Federation of State High School Associations. The genesis and operation of a pilot program under this contract in the State of Washington for the academic year 1982-83 is illustrated by the following case.

Chris Thompson of Seattle was left paralyzed by a football injury suffered in 1975, when he was a fifteen-year-old sophomore at West Seattle High School. Marty Wittman suffered a similar accident in December of 1982 when, as a sixteen-year-old sophoinore at Curtis High in Tacoma, he was injured while competing in an interscholastic wrestling match. Because of these injuries, the students' lifestyles-as well as those of their families-were altered drastically. Thompson waited and wondered whether he would ever receive any of the $\$ 6.5$ million a jury awarded him in 1982, seven years after his injury. Wittman and his family, on the other hand, benefited shortly after his accident from an insurance policy created because of the lawsuit Thompson had filed and won.

The new policy had been endorsed by the Washington Interscholastic Activities Association, which was exceedingly anxious to provide better coverage for its member schools $m$ light of the Thompson case. The plan is essentially a no-fault policy for unlimited medical expenses plus up to $\$ 300$ per week wage loss, payable to catastrophically injured athletes. The premium payable by the school is approximately one dollar per year for each athlete covered. ${ }^{64}$ The plan has a $\$ 10,000$ deductible.

63. On the flexibility of the market to right the wrongs of the tort system, see O'Connell, Harnessing the Liability Lottery: Elective First-Party No-Fault Insurance Financed by Third-Party Tort Claims, 1978 WASH. U.L.Q. 693, 693-94, 697.

64. This cost may well be absorbed-indeed dwarfed-by savings in liability insurance costs stemming from tort waivers. And yet Joseph L. Keamey, Commissioner of the Western (Collegiate) Athletic Conference, in commenting on the possible adoption of the program by the NCAA, "consistently justifies the program on the basis that regardless of any legal obligation, colleges have a moral obligation for the well-being of their student-athletes. The . . plan, as [NCAA Director of 
When an injury occurs and the medical expense and/or wage loss exceeds $\$ 10,000$, the policy goes into effect.

The plan provides for expenses such as medical and rehabilitation costs, transportation costs, costs of remodeling the family hoine to accommodate a wheelchair, and wages lost by parents who have to miss work to care for the injured athlete. The policy also specifies that it will provide up to $\$ 300$ of income a week for life if the beneficiary has less than $\$ 300$ of income from other sources. Nothing, however, is paid for pain and suffering. The coverage goes into effect only if the beneficiary and his family agree not to file a tort suit against the school, school district, or state athletic association. In other words, no one has to sign away his right to sue, but the plan provides that its benefits are in heu of tort litigation.

Wittman, who was hospitalized for six inonths following the injury and then underwent rehabilitation for two days a week on an out-patient basis, was the first beneficiary of the plan. In addition to prompt receipt of all related medical expenses, Wittman received a new van, which was modified to include hand controls and a wheelchair lift. The Wittman home was also remodeled to accommodate his condition. ${ }^{65}$

In Thompson's case, the verdict in his favor did not end his uncertainty. The verdict in King County Superior court was appealed to the State Supreme Court, and the case was not settled until November of 1983 , almost two years after the verdict, for $\$ 3.9$ million. ${ }^{66}$

Thompson had to go to court because he had no other recourse. And going to court offered no guarantees. As Doug McBroom, Thompson's attorney, commented after efforts-both before and during trialto settle Thompson's suit out of court failed, "We rolled the dice in the courtroom."

\section{CONCLUSION}

If, as seems evident, tort law as it apphes to personal injury disadvantages both injured and injuring parties, why shouldn't contractual schemes be devised to alter tort law to the mutual advantage of both parties? ${ }^{68}$ Such devices are available and indeed are in place for seriously

Finance Richard D.] Hunter said, represents 'a lot of work of a lot of people' to fulfill that moral obligation." NCAA NEws, Oct 8, 1983, at 1 .

65. Seattle Times, July 22, 1983, at DI.

66. Conversation between author and Douglas McBroom, plaintiff Thompson's lawyer, (July 1984). See also supra text accompanying notes 23-25.

67. Seattle Times, July 22,1983 , at D1.

68. On this point-and the pertinent writings of economist Ronald Coase-see O'Connell, The Interlocking Death and Rebirth of Contract and Tort, 75 Mich. L. REv. 659, 667-73, 683-84 (1977).

I have discussed elsewhere how my various proposals for no-fault reform-both legislative and contractual-relate to each other and how any one of them can serve as either an end in itself or as a 
injured high school athletes. Surely others will have the wit and wisdom to follow (and thereby avoid) suit.

transition to more sweeping reform, like ambitious social insurance scheines to replace tort liability. See O'Connell, supra note 26, at 631-32.

For iny proposal dealing with the coordination of a statute and contracts whereby defendants to tender claimants' net economic loss, see iny forthcoming manuscript, Coordinated Legislativc and Contractual Alternatives to Tort Law, in Law \& Contemporary Problems, in a symposium based on a conference entitled, "Medical Malpractice: Can the Private Sector Find Relief," Feb. 21-22, 1985 in Washington D.C. The conference was sponsored by The Urban Institute in cooperation with The Program on Legal Issues im Hcalth Care, Duke University School of Law. 